Discussion Paper No. 05-88

\title{
Integration and Reorganisation of Industrial R\&D: Deficits and Perspectives of Empirical Research
}

Christoph Grimpe

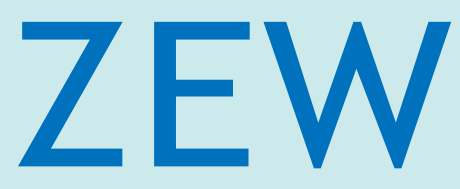

Zentrum für Europäische Wirtschaftsforschung $\mathrm{GmbH}$

Centre for European

Economic Research 
Discussion Paper No. 05-88

\title{
Integration and Reorganisation of Industrial R\&D: Deficits and Perspectives of Empirical Research
}

\author{
Christoph Grimpe
}

Download this ZEW Discussion Paper from our ftp server:

ftp://ftp.zew.de/pub/zew-docs/dp/dp0588.pdf

Die Discussion Papers dienen einer möglichst schnellen Verbreitung von neueren Forschungsarbeiten des ZEW. Die Beiträge liegen in alleiniger Verantwortung der Autoren und stellen nicht notwendigerweise die Meinung des ZEW dar.

Discussion Papers are intended to make results of ZEW research promptly available to other economists in order to encourage discussion and suggestions for revisions. The authors are solely responsible for the contents which do not necessarily represent the opinion of the ZEW. 


\section{Non-technical summary}

The effects of mergers and acquisitions (M\&A) on industrial research and development (R\&D) and innovative capabilities of companies have been widely discussed in management literature. Empirical studies on this topic can be grouped under three major research questions. The first group analyses the relationship between the realisation of M\&A transactions and the existence of certain organisational characteristics, like R\&D intensity, as an indicator of technological wealth, or relatedness of technologies employed. Some studies show that technology acquisition as a merger motive usually goes along with a high R\&D intensity of the target company and a close technological relatedness between the two companies. The second group of studies is concerned with the analysis of the effects of M\&A transactions on R\&D input and output. In this respect some studies assume that by acquiring external technological knowledge, some companies substitute their own R\&D activities. However, this does not necessarily lead to an increase in the R\&D output and thus in the innovative capabilities of a company. Apparently, the integration of external technologies into the technological portfolio of a company is rarely successful. That is why a third group of studies analyses the connections between post merger integration activities and the successful integration of R\&D.

There are nine studies that are concerned with this issue. In order to examine these studies with respect to the contributions for the management of R\&D integration activities, first a conceptual framework is derived based on a comprehensive set of theoretical hypotheses. Afterwards, a critical analysis of the empirical studies is presented and shortcomings in assessing the hypotheses are outlined. Regarding content and methods, the studies turn out to have serious deficits. Therefore, the hypotheses cannot be analysed sufficiently. Finally, implications for further research are developed. 


\title{
Integration and Reorganisation of Industrial R\&D: Deficits and Perspectives of Empirical Research
}

\author{
Christoph Grimpe
}

December 2005

\begin{abstract}
The combination of research and development units following a merger or an acquisition usually requires a broad and widespread integration project to ensure that a company's innovative capabilities are carried forward into the future. Previous research has shown, however, that the combined companies tend to produce fewer innovations after the transaction than before. Based on a set of theoretical hypotheses, nine empirical studies are analysed with respect to their contribution to the research problem. The review shows substantial shortcomings in content and methodology which do not allow the hypotheses to be evaluated adequately.
\end{abstract}

Keywords: $\quad$ Post Merger Integration, Reorganisation, Research and Development, Literature Review

JEL-Classification: G34, M10, M54

Address: $\quad$ Centre for European Economic Research (ZEW)

Department of Industrial Economics and International Management P.O. Box 103443

D-68034 Mannheim (Germany)

Tel.: $\quad$ + $\quad$ +49 (0) 621-1235-381

Fax: $\quad$ +49 (0) 621-1235-170

E-Mail: grimpe@zew.de 


\section{Introduction}

The effects of mergers and acquisitions (M\&A) on industrial research and development $(\mathrm{R} \& \mathrm{D})$ and innovative capabilities of companies have been widely discussed in management literature. Empirical studies on this topic can be grouped under three major research questions. The first group analyses the relationship between the realisation of M\&A transactions and the existence of certain organisational characteristics, like R\&D intensity, as an indicator of technological wealth, or relatedness of technologies employed. Süverkrüp (1992) shows that about one fourth of all transactions aim at acquiring external technological knowledge as a substitute or complement of own technologies. Chakrabarti and Burton (1983), Hall (1987), Link (1988), Brenner (1990), Bühner (1990), Hall (1990), Süverkrüp (1992), Haag (1995) and Hagedoorn and Duysters (2002b) demonstrate that technology acquisition as a merger motive usually goes along with a high R\&D intensity and technological relatedness of both companies in order to realise the potential for value growth.

A second group of empirical studies explores the effect of M\&A transactions on R\&D inputs and outputs. The basic model introduced by Hitt, Hoskisson and Ireland (1990) assumes a negative relationship between the realisation of M\&A transactions and the propensity to perform internal R\&D activities which is attributed to direct and indirect effects of the transaction. Direct effects consist of a substitution of a company's own R\&D activities by acquiring external technological knowledge. Contrary to that, indirect effects appear when an increase in company size leads to an organisational form with a higher degree of formal control that is detrimental to innovation (Burns and Stalker 2001; Hitt, Hoskisson and Ireland 1990).

Pieper (1998) applies this model to technological substitution and complementing effects: Decreasing internal R\&D inputs can be reported in cases where the M\&A transaction has led to the acquisition of technological knowledge in identical fields of application, because they have been substituted. If the acquirer strives to complement its own R\&D activities and, therefore, acquires a company working in non-identical fields of application, this - contrary to expectations - does not lead to an increasing number of patents pending or granted. Instead, R\&D outputs and, as a result, innovative capabilities, decrease. Thus, integrating external technological knowledge obviously proves to be less successful. This indicates that integration is an important prerequisite for success whereas integration success is conceptualised as the degree of value growth potential realised by transferring resources in the course of integrating the R\&D functions. Value growth in this sense may originate from a combination of technological knowledge as 
well as from exploiting economies of scale or eliminating redundancy (Singh and Montgomery 1987). From this it follows that particularly the organisational integration of $R \& D$ following an M\&A transaction has a significant share in sustaining a company's long-term innovative capabilities.

This leads to a third group of studies investigating relations between post merger integration activities and the successful integration of R\&D. A first literature review on this research question, however, only yields nine studies dealing with these issues despite the high relevance of the topic. The results of these studies with respect to success relevant integration activities will be discussed in the following. For this purpose, a conceptual framework is derived based on a comprehensive set of theoretical hypotheses. Afterwards, a critical analysis of the empirical studies is presented and shortcomings in assessing the hypotheses are outlined. Finally, implications for further research are developed.

\section{Aspects of integrating $R \& D$ after a merger}

The research problem of post merger integration can be split up into two separate but interdependent aspects. The first deals with the question of how far the acquired company or the acquired R\&D is actually intended to be integrated into the acquirer. The acquirer thus has to determine the degree of integration, which is conceptualised as the extent of resource transfers between the two companies (Gerpott 1995). In a sense, integration itself can be understood as a design option within the integration process. There are numerous degrees of integration that may be arranged on a virtually continuous scale from full integration on the one side and a largely independent continuation of business on the other side although the perception of a continuous and even linear scale may only serve as a pragmatic reduction of complexity. Haspeslagh and Jemison (1991) suggest a more sophisticated understanding of the degree of integration. Based on the need for strategic interdependence and organisational autonomy they classify four distinct approaches, which they call "preservation”, "holding”, "symbiosis” and "absorption" in the order of an increasing degree of integration.

For all of the integration approaches except preservation, suitable integration measures and instruments have to be planned and implemented. This is the second aspect in the process of integrating $R \& D$ activities after a merger. These design options for integration involve reorganisation processes in one or both companies that aim at harmonising the two R\&D organisations according to the corporate technology strategy. Moreover, reorganisation processes are regularly influenced by certain constraints and context factors that have to be considered. For example, for the integration of a small, inno- 
vative company different measures are necessary than for the merger of larger companies. Empirical studies dedicated to this research question may hence be assigned to the conceptual framework shown in figure 1.

Figure 1: Conceptual framework of the studies

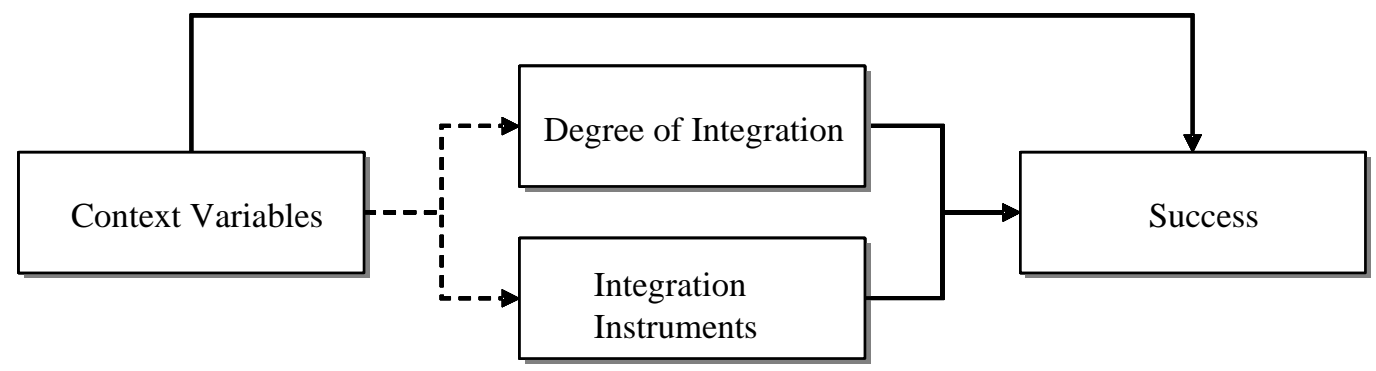

The model is based on a set of hypotheses and describes the influence of externally determined context variables on the one hand and configuration options on the other hand on integration success. Interactions showing the influence of a context variable on the importance of the degree of integration or the integration measures on success are represented by dashed arrows. Success as the dependent variable is conceptualised as integration success, which is made up of a number of success indicators. To shed light on the success variables employed by the empirical studies, we draw a simplistic distinction between economic, technological and integration related success indicators. Within these, technological success indicators play a key role in evaluating the effect of the transaction on, for example, patent output or innovative capabilities in terms of new products as many transactions are technology-grafting acquisitions. A high technological success should, consequently, also positively influence economic success indicators as, for instance, sales, earnings or market share increases. Innovative capabilities of a company, however, almost always directly depend on the employees in R\&D. Vitt (1998) shows that many of the so-called key inventors leave the company after a transaction or change to a management position. In that case, future innovative capabilities are immediately at risk. Whether an R\&D integration is successful or not can therefore also be measured by the integration process, with indicators such as employee turnover and job satisfaction, as well as perceived stress and insecurity (Cartwright and Cooper 1990).

The first hypothesis depicted by the model states that value growth potentials may not be realised without integrating the companies and that they can be even better realised with an increasing degree of integration. The reason for this is the presumption that even if $R \& D$ only plays a subordinate role in an acquisition, the management has to 
coordinate the R\&D resources of both companies in some way. This assumes a positive relationship between the degree of integration and success:

H1: The higher the degree of integration, the higher the integration success will be.

With respect to the integration measures, Tushman, Newman and Romanelli (1988) characterise the structures, processes and systems of a company as central dimensions that have to be addressed during a reorganisation. Structures refer to formal organisational arrangements and the structural linking of different organisations. It can be assumed that the use of instruments for a structural linking of the organisations involved serves as a basis for utilising value growth potentials and will, therefore, increase integration success. This leads to the second hypothesis:

H2: The structural linking of the companies involved will increase the integration success.

In contrast to that, the term "processes" focuses on a redesign of the innovation process within $R \& D$ as well as in coordination with other company functions. New processes have to be defined that account for the existence of the acquired company and that integrate the target into the whole organisation (Brockhoff 1989). It arises as third hypothesis:

H3: The redesign of processes within the companies involved will increase the integration success.

Systems include organisational arrangements and are mainly used as coordination instruments because they substitute - to a certain extent - case-by-case decisions by a general rule (Gutenberg 1962). Systems typically comprise information, reporting and control systems as well as career and incentive systems which, similar to structures and processes, have to be adjusted within the companies involved. As a consequence, leaving out an adjustment of those management systems may result in control and information deficits that hamper the realisation of value growth potentials. This leads to the fourth hypothesis:

H4: Harmonising the management systems within the companies involved will increase the integration success.

With regard to $R \& D$ integration activities another dimension that focuses on the resources to be transferred becomes important. As R\&D activities put special emphasis on intangible resources it might be feasible to distinguish between intangible knowledge resources on the one hand and human resources on the other hand. Besides the explicit knowledge that can be documented, Rüdiger and Vanini (1998) point to the special im- 
portance of implicit or tacit knowledge for R\&D. Such knowledge can only be transferred via personal communication and interaction. In this case, knowledge and human resources become congruent with each other.

The resource dimension thus provides two hypotheses. When reorganisation processes are recognised as the introduction of organisational innovations (Hauschildt 1997) resistance to this change can be anticipated. Instruments suitable for overcoming resistance may reduce interferences in exploiting value growth potentials and, hence, increase integration success. Moreover, it seems obvious that the transfer of knowledge possesses a high importance for R\&D. Possible instruments could cover the encouragement of communication or an exchange of personnel. The resulting hypotheses turn out to be:

H5: Overcoming the resistance to change will increase the integration success.

H6: The transfer of knowledge between the companies involved will increase the integration success.

Apart from the degree of integration and subsequent integration measures there are several context variables relevant for the analysis as they influence the success as well as the importance of certain integration instruments. Various situational variables are conceivable with those most prominent being the relatedness of the involved companies with respect to products, markets or technologies, the size or relative size of the target company or the cultural distance between the companies. Generally speaking, a higher relatedness will tend to result in a higher success as it becomes easier to identify value growth potentials (Singh and Montgomery 1987):

H7: The higher the relatedness of the involved companies with respect to products and technologies, the higher the integration success will be.

Another context variable influencing the success may be the size or relative size of the target company. It can be assumed that a larger transaction or a greater relative size provides greater chances for realising value growth potentials than a smaller transaction:

H8: The larger the target company compared with the acquiring company the higher the integration success will be.

Furthermore, cultural differences may be included within the analysis. A higher cultural distance can be supposed to complicate the realisation of value growth potentials as it may result in communication problems on various levels.

H9: The lower the cultural distance between the involved companies, the higher the integration success will be. 
The hypotheses have specified the direct influence of the context variables on success. Moreover, indirect effects representing interactions can be formulated using any combination of context and integration variables which shall, due to complexity, be left out here. The following paragraph will portray the empirical studies on the post merger integration that can be subsumed under the conceptual framework outlined above.

\section{Results of empirical studies on the post merger integration of R\&D}

A total of nine studies can be identified with regard to issues of $R \& D$ integration. According to the conceptual framework, results will be differentiated in those focussing on the degree of integration ("integration as an option") and in those dealing with single integration instruments and measures (“options for the integration”) in order to derive insights into the relevance of both aspects for success. Integration measures will be split up into the dimensions mentioned before: structures, processes, systems and resources. Classifying the integration measures, however, is not always unambiguous. It should therefore be understood as an approximate assignment. Moreover, context variables used in the studies are included. As outlined before, integration success is measured using a wide range of success indicators. The presentation differentiates between economic, technological and integration related success indicators. Tables 1 and 2 show the results of the studies in detail whereas the further discussion is confined to major aspects or those aspects shared by more than one study. It becomes clear that no study addresses all the aspects identified as relevant for the post merger integration of R\&D. As a result, there is no evidence for a comprehensive discussion of the research problem. Of the nine studies, five work on the degree of integration while seven studies focus on certain integration measures. Only four studies deal with both aspects. Six studies include context variables in the analysis. Economic and technological success indicators are discussed in most studies while integration success indicators are considered in only one study - and only rudimentarily. The following paragraph will take a closer look at the single studies on the basis of the relationships between the variables, as analysed above. 
Table 1: $\quad$ Empirical studies on the success of post merger integration

\begin{tabular}{|c|c|c|c|c|c|c|}
\hline \multirow[t]{2}{*}{ Authors } & \multirow[t]{2}{*}{ Profile of the study } & \multirow[t]{2}{*}{ Degree of integration } & \multicolumn{4}{|c|}{ Integration instruments } \\
\hline & & & Structures & Processes & Systems & Resources \\
\hline $\begin{array}{l}\text { Souder/Chakrabarti } \\
\text { (1984) }\end{array}$ & $\begin{array}{l}n=16 \text { acquisitions of } 8 \text { US } \\
\text { companies, } \\
1974-1984\end{array}$ & & & & $\begin{array}{l}\text { association with } \\
\text { corporate management } \\
\text { planning systems }\end{array}$ & sharing of technology \\
\hline $\begin{array}{l}\text { Chakrabarti/Souder } \\
\text { (1987) }\end{array}$ & $\begin{array}{l}\mathrm{n}=31 \text { US-Acquisitions, } \\
1970-1980\end{array}$ & $\begin{array}{l}\text { integration between } \\
\text { division and corporation }\end{array}$ & & & formalization & $\begin{array}{l}\text { sharing technological } \\
\text { knowledge }\end{array}$ \\
\hline Chakrabarti (1990) & $\begin{array}{l}\mathrm{n}=31 \text { US-Acquisitions, } \\
1970-1980\end{array}$ & level of integration & & & formalization & $\begin{array}{l}\text { communication factors, } \\
\text { joint project, job rotation }\end{array}$ \\
\hline $\begin{array}{l}\text { Süverkrüp (1992), } \\
\text { Chakrabarti/ } \\
\text { Hauschildt/ } \\
\text { Süverkrüp (1994) }\end{array}$ & $\begin{array}{l}\mathrm{n}=30 \text { technologically } \\
\text { motivated transactions } \\
\text { between German und US } \\
\text { Companies, } \\
\text { 1978-1987 }\end{array}$ & $\begin{array}{l}\text { autonomy of the } \\
\text { division }\end{array}$ & $\begin{array}{l}\text { hierarchy support by the } \\
\text { parent company }\end{array}$ & & $\begin{array}{l}\text { formalization, increase } \\
\text { of } R \& D \text { budget with } \\
\text { increase in formalization }\end{array}$ & personal communication \\
\hline Gerpott (1995) & $\begin{array}{l}\mathrm{n}=92 \text { German } \\
\text { acquisitions, } \\
1988\end{array}$ & degree of integration & $\begin{array}{l}\text { R\&D decision } \\
\text { centralisation, } \\
\text { integration team } \\
\end{array}$ & & & $\begin{array}{l}\text { internal/cross-company } \\
\text { meetings, employee } \\
\text { support/information }\end{array}$ \\
\hline Haag (1995) & $\begin{array}{l}\mathrm{n}=66 \text { transactions in } 32 \\
\text { companies, } \\
1992\end{array}$ & & & & & $\begin{array}{l}\text { sharing technological } \\
\text { knowledge, } \\
\text { consideration and } \\
\text { control of psychological } \\
\text { factors } \\
\end{array}$ \\
\hline $\begin{array}{l}\text { Birkinshaw/ } \\
\text { Bresman/Hakanson } \\
(2000)\end{array}$ & $\begin{array}{l}\mathrm{n}=219 \text { employees } \\
\text { questioned about three } \\
\text { acquisitions of Swedish } \\
\text { companies, } \\
\text { 1991, 1992, } 1996\end{array}$ & level of integration & & & & $\begin{array}{l}\text { international staff/joint } \\
\text { R\&D meetings, culture } \\
\text { awareness seminars, } \\
\text { mixed project teams, } \\
\text { personnel rotation, joint } \\
\text { R\&D personal training, } \\
\text { communication } \\
\text { processes }\end{array}$ \\
\hline $\begin{array}{l}\text { Hagedoorn/ } \\
\text { Duysters (2002a) }\end{array}$ & $\begin{array}{l}\mathrm{n}=201 \text { acquisitions of } 35 \\
\text { companies, } \\
1986-1992\end{array}$ & & & & & \\
\hline $\begin{array}{l}\text { Puranam/Singh/ } \\
\text { Zollo (2003) }\end{array}$ & $\begin{array}{l}\mathrm{n}=207 \text { acquisitions of } 49 \\
\text { companies, } \\
1988-1998\end{array}$ & $\begin{array}{l}\text { level of organisational } \\
\text { integration }\end{array}$ & & & & \\
\hline
\end{tabular}




\begin{tabular}{|c|c|c|c|c|}
\hline \multirow[t]{2}{*}{ Authors } & \multirow[t]{2}{*}{ Context variables } & \multicolumn{3}{|c|}{ Success indicators } \\
\hline & & Economic & Technological & Integration related \\
\hline $\begin{array}{l}\text { Souder/Chakrabarti } \\
\text { (1984) }\end{array}$ & & $\begin{array}{l}\text { sales/profit/market share growth, } \\
\text { ROI, broadening of customer base }\end{array}$ & technological innovation & \\
\hline $\begin{array}{l}\text { Chakrabarti/Souder } \\
\text { (1987) }\end{array}$ & & $\begin{array}{l}\text { sales/profit/market share growth, } \\
\text { ROI, broadening of customer base }\end{array}$ & technological innovation & \\
\hline Chakrabarti (1990) & $\begin{array}{l}\text { technological/product-market relatedness, } \\
\text { changes in competitive environment }\end{array}$ & $\begin{array}{l}\text { sales/profit/market share growth, } \\
\text { ROI, broadening customer base }\end{array}$ & technological innovation & \\
\hline $\begin{array}{l}\text { Süverkrüp (1992), } \\
\text { Chakrabarti/ } \\
\text { Hauschildt/ } \\
\text { Süverkrüp (1994) }\end{array}$ & $\begin{array}{l}\text { technological insecurity, cultural } \\
\text { differences, prior experience with } \\
\text { acquisition, size, crisis-manager } \\
\text { orientation, differences in production } \\
\text { structure, personal reasons for selling }\end{array}$ & production/market/financial success & $\begin{array}{l}\text { success of applied research, } R \& D \\
\text { success }\end{array}$ & \\
\hline Gerpott (1995) & $\begin{array}{l}\text { acquisition experience, influence potential } \\
\text { over target, size, market/technological } \\
\text { relatedness, prior acquiree profitability, } \\
\text { deal attitude }\end{array}$ & $\begin{array}{l}\text { operating profit trend change of } \\
\text { acquired firm, sales trend change of } \\
\text { acquiring and acquired firm }\end{array}$ & & $\begin{array}{l}\text { level of organisational integration of } \\
\text { R\&D activities desired vs. achieved }\end{array}$ \\
\hline Haag (1995) & relatedness of core technologies & $\begin{array}{l}\text { turnover, profit, long-term } \\
\text { competitive advantage }\end{array}$ & $\begin{array}{l}\text { innovative capabilities, know-how- } \\
\text { transfer }\end{array}$ & \\
\hline $\begin{array}{l}\text { Birkinshaw/ } \\
\text { Bresman/Hakanson } \\
(2000)\end{array}$ & $\begin{array}{l}\text { deal attitude, prior experience with } \\
\text { acquisition }\end{array}$ & & $\begin{array}{l}\text { change in } \mathrm{R} \& \mathrm{D} \text { output, technology } \\
\text { transfer between operations }\end{array}$ & \\
\hline $\begin{array}{l}\text { Hagedoorn/ } \\
\text { Duysters (2002a) }\end{array}$ & $\begin{array}{l}\text { technological/product-market } \\
\text { relationship, R\&D intensity, size, } \\
\text { international character of M\&A, } \\
\text { acquisition experience }\end{array}$ & & patent intensity growth & \\
\hline $\begin{array}{l}\text { Puranam/Singh/ } \\
\text { Zollo (2003) }\end{array}$ & & & product launches after acquisition & \\
\hline
\end{tabular}




\subsection{The effects of the degree of integration}

The studies focussing on the first aspect, i.e. the degree of integration ("integration as an option”), employ various measurement approaches. Chakrabarti and Souder (1987) and Chakrabarti (1990) characterise it as the extent of collaboration between the employees of the corporate and the acquired division. Others draw on a number of variables forming a construct or, like Gerpott (1995), revert to a direct evaluation by the informants. Birkinshaw, Bresman and Hakanson (2000) refer to the integration approaches introduced by Hapeslagh and Jemison (1991). A very simplified approach is used by Puranam, Singh and Zollo (2003) who only distinguish between a low and high degree of integration subject to the existence of the target company within a company database one year after the transaction.

Due to the variety of measures used a comparison of the results of the studies proves to be difficult. This situation is reflected by diverging results. Chakrabarti and Souder (1987), Chakrabarti (1990) as well as Süverkrüp (1992) and Chakrabarti, Hauschildt and Süverkrüp (1994) can report a positive influence of a higher degree of autonomy, i.e. a lower degree of integration, on success. They explain this by referring to the potential for conflict, which is much lower when there is a high degree of autonomy. At the same time, dedication and creativity are maintained in the acquired company. In contrast to that, Birkinshaw, Bresman and Hakanson (2000) can observe a positive influence of a high degree of integration. According to them, this is because of the better opportunities to realise value growth potentials. Puranam, Singh and Zollo (2003) reason that a high degree of integration may interfere with short-term product development but may be highly beneficial in the long term. To sum up, the studies argue on the whole for a positive relationship between the degree of integration and success. $H 1$, therefore, receives support.

\subsection{The effects of integration measures}

With respect to the integration measures, a total of seven studies examine relationships between the variables. The studies exhibit a strong emphasis on the resource dimension. All of them analyse relations within this dimension, while the structures dimension is addressed by two studies and the systems dimension by four. Surprisingly, the processes dimension has been left out completely in the studies. Starting with structures, Süverkrüp (1992) and Chakrabarti, Hauschildt and Süverkrüp (1994) analyse the effect of a hierarchy support by the parent company. Their study considers such factors as the 
constancy of responsibilities or the hierarchical linking. The effect, however, remains ambiguous. Gerpott (1993, 1994) emphasises the structural support of the integration process with the aid of an "acquisition manager" and an integration team. With respect to the allocation of decision making authorities he shows that a lower degree of delegation to the target company but a higher degree of participation in decisions increases the success of the acquisition. Altogether, the results seem to be rather fragmented with respect to $H 2$. A positive influence can be attributed to single integration measures. The general importance of a structural linking, though, remains unclear.

Up to now, insights into the process dimension are missing. Therefore, it is not possible to decide on $H 3$. Regarding the systems dimensions, previous results are scarce as well. Souder and Chakrabarti (1984) analyse the "association with corporate management planning systems" and report a strong positive influence on success. Chakrabarti and Souder (1987) and Chakrabarti (1990) examine the "level of formalisation" in planning, resource allocation, $R \& D$ project selection and other management decisions and show a negative effect on success. Süverkrüp (1992) and Chakrabarti, Hauschildt and Süverkrüp (1994) analyse the degree of formalisation and report a negative relationship with the technological success of a transaction. To sum up, the studies tend to report a positive influence of a systems adjustment. This should not, however, coincide with an increase in formalisation. $\mathrm{H} 4$, therefore, receives some support.

Seven studies investigate aspects within the resource dimension. Three of them concentrate on the exchange of technological knowledge, finding that it is in a positive relationship with technological success. Another factor selected for consideration is the effect of communication and information policy on success, which is included in four studies. Chakrabarti (1990) and Birkinshaw, Bresman and Hakanson (2000) examine information quality and quantity, both being positively associated with the success. Süverkrüp (1992) and Chakrabarti, Hauschildt and Süverkrüp (1994) detect a slightly positive effect of personal communication on economic success. Gerpott (1993) includes information brochures in his analysis and points to their negative effect on the degree of integration achieved. Birkinshaw, Bresman and Hakanson (2000) consider the communication process in terms of "human integration" to be a precondition for further integration, in order to realise value growth potentials.

Moreover, a number of studies investigate a transfer of personnel, job rotation or joint project work by employees of the companies involved. Chakrabarti (1990) and Birkinshaw, Bresman and Hakanson (2000) point to the positive effect of joint projects and job rotation. Gerpott $(1993,1995)$ focuses on training and workshops as means of facilitation of adaptation that implicate a positive effect on success. Birkinshaw, Bresman and Hakanson (2000) observe similar effects. To sum up, the resource dimension 
unveils a multitude of success relevant aspects including information and communication, joint projects, job rotation and motivational instruments like training or the development of incentive systems. $\mathrm{H} 5$ and $H 6$, therefore, receive support.

\subsection{The effects of context variables}

Beside the degree of integration and integration measures, the majority of the empirical studies include context variables into their analysis. The influence of these context variables will be analysed in the following. Chakrabarti $(1990)$, Gerpott $(1993,1995)$ and Hagedoorn and Duysters (2002a) focus on product, market and technology relatedness. While Chakrabarti (1990) cannot report a significant influence, Gerpott $(1993,1995)$ refers to highly different effects of integration instruments on success depending on the characteristics of the context variable. He shows that the delegation of autonomy to the target company will only be successful if the companies exhibit a low degree of relatedness with respect to products and technologies. Hagedoorn and Duysters (2002a) report a strong positive effect of product, market and technology relatedness on the technological success of a transaction. Haag (1995) investigates the relatedness of core technologies only regarding their technological relatedness, exhibiting a significant positive effect on success. To sum up, $H 7$ receives support.

With respect to relative size, results are mixed. Süverkrüp (1992) and Chakrabarti, Hauschildt and Süverkrüp (1994) can report an interesting result: they demonstrate that the size of acquirer and target company are highly correlated leading to a single construct that exhibits a significant positive effect on the technological success but a slightly negative effect on economic success. This result is supported by Hagedoorn and Duysters (2002a) who find a decreasing technological success with the size difference becoming greater. $H 8$, therefore, receives only some support by the findings.

Finally, several studies investigate the influence of cultural distance between the companies involved. On the one hand, Süverkrüp (1992) and Chakrabarti, Hauschildt and Süverkrüp (1994) detect a negative effect of increasing cultural differences on success, while Hagedorn and Duysters (2002) on the other hand can find a positive effect of increasing cultural distance. The findings for $H 9$ thus remain unclear.

\subsection{Measurement of integration success}

To shed light on the way success was measured by the studies we refer to the distinction between economic, technological and integration related success. When examining the studies, it turns out that none of them measures success according to all three dimen- 
sions mentioned. The emphasis is on economic and technological success indicators. Within the economic success dimension nearly all studies focus on changes in sales, earnings or market share as a result of the M\&A transaction. Furthermore, some studies consider the extent to which value growth potentials could be realised. With respect to technological success, studies aim at measuring innovative capabilities. Indicators used comprise the $R \& D$ output in terms of patents or new products or the resource transfers realised in $R \& D$. In the context of integration related indicators, only the difference between the targeted and achieved degrees of integration is taken into account, while no other indicators are applied. To sum up, there is anything but a consensus on what success indicators play a key role in measuring integration success.

This dissension is reflected by the different ways of indicator measurement. A majority of the studies relies on an assessment of success given by the interviewed employees who typically rank among higher management. There is no study that can be identified as interviewing several persons on the same issue, which could have increased the validity of the information given. Although Souder and Chakrabarti (1984), Chakrabarti and Souder (1987) and Chakrabarti (1990) question several persons per company, they ask each person about different issues. Other authors refer to success indicators that are not subject to the evaluation of a single informant. Hagedoorn and Duysters (2002a), for example, revert to patent databases to estimate the growth of companies' patent intensity. Puranam, Singh and Zollo (2003) evaluate the number of new products brought out, based on an analysis of databases and documents. However, there is no study that uses a combination of objective and interview-based success indicators. Altogether, the use of different success indicators and the inconsistent manner of their measurement considerably complicate the comparability of the studies.

\section{Deficits and perspectives of integration research}

In the following, the above-mentioned studies will be criticized systematically in order to emphasize crucial shortcomings. Furthermore, it is interesting in how far there are results of other studies that deal with the question of post merger integration, but without taking R\&D explicitly into account. In a third step, implications for future research will be devised.

\subsection{Critical assessment of the studies}

The assessment of the studies can be distinguished into content and method related aspects. A first consequence of the reported inconsistencies in measuring success, how- 
ever, is the need for a careful interpretation of the assessment of the hypotheses. In any case, the presentation of the results has made clear that the post merger integration of $R \& D$ should not be analysed in a fragmented way, i.e. by referring exclusively to a single aspect, and that any analysis requires the inclusion of appropriate success indicators. Tables 1 and 2 gave an account of the relevant variables employed in the studies and, in doing so, revealed a number of shortcomings. Accordingly, the summary evaluation of the nine hypotheses in table 3 remains unclear.

Table 3: $\quad$ Summary evaluation of the hypotheses

\begin{tabular}{lll}
\hline No. & Hypothesis & Result \\
\hline H1 & degree of integration & $(\mathbf{x})$ \\
\hline H2 & structural linking & $(\mathbf{x})$ \\
\hline H3 & redesign of processes & no result \\
\hline H4 & harmonising management systems & $\checkmark$ \\
\hline H5 & overcoming resistance & $\checkmark$ \\
\hline H6 & transfer of knowledge & $(\checkmark)$ \\
\hline H7 & product-market and technological relatedness & $\checkmark$ \\
\hline H8 & size/relative size of the target company & $(\mathbf{x})$ \\
\hline H9 & cultural differences & \\
\hline$\checkmark$ supported; $(\checkmark)$ partially supported; (x) result unclear & \\
\hline
\end{tabular}

In detail, the degree of integration, structures and processes still need to be clarified. While there are very different results for the degree of integration due to strongly diverging variable measures, the structures and processes are limited to an extremely small number of variables. Moreover, the success indicators, especially for integration success which is extremely relevant for $R \& D$, have received little attention. The effects of the merger or acquisition on employee turnover and thus the loss of technological knowledge and inventive capacities, as well as insecurity and fear of the future felt by the employees, can therefore not be estimated.

In addition, there are some methodological shortcomings. One first critical point is the insufficient sample size that several studies rely on that does not allow for representative results. Moreover, it has to be criticised when studies choose a rather long period of analysis to obtain a larger sample but measure success at one single point in time only. This period can feature numerous success relevant events such that the success measured may no longer remain assignable to the integration itself. 
Moreover, there are critical points focussing on empirical success factor research in general (Nicolai and Kieser 2002). Mainly due to estimation reasons, the studies exclusively investigate linear relationships between the variables. With these relationships, however, it would be possible to increase success virtually endlessly. In fact, plausible relationships should be concave or inverted U-shaped indicating an optimisation of benefits and costs from choosing an integration measure. Apart from that, interviewing only one key informant tends to lead towards a systematically inflated estimation of success and an ex-post rationalisation of the measures employed ("key informant bias"; Ernst 2002). Furthermore, especially in case of an M\&A transaction, there might be diverging evaluations from those affiliated with the acquiring and those with the target company. Finally, it could be that only those companies that are able to report rather positive experiences agreed to participate. In this case, the sample will not be representative ("selection bias").

\subsection{Further results}

Based on the findings presented above, several implications for further research could be derived. However, for an integrated approach it seems feasible to additionally analyse those studies that can be subsumed under the same conceptual framework made up of integration, context and success variables but that do not particularly focus on the $R \& D$ function but on the whole company. This review of literature dealing with general issues of post merger integration may provide additional clarifying aspects and indications for content and methods. All in all, 19 additional studies since 1990 apply this framework, but they will not be analysed in detail here. Instead, the following section will refer explicitly to the shortcomings already outlined, in order to estimate in how far they can also be found in general analyses on post merger integration.

With respect to the degree of integration, the hypotheses had very ambiguous results, which was largely due to the different variable measures. Angwin and Wensley (1997) go back to the integration strategies as introduced by Hapeslagh and Jemison ("preservation”, "holding”, “symbiosis” and "absorption”). However, a direct link between any one strategy and success is missing. The approach of Morosini and Singh (1994) and Morosini, Shane and Singh (1998) is similar, although it refers to only three integration strategies (“integration”, “restructuring” and “independence”). Datta and Grant (1990), Datta (1991) and Weber (1996) draw on a number of variables forming a construct to measure the degree of integration. Bamberger (1994) uses a pragmatic approach by differentiating only between a low (independent continuation of business), medium (joint operation of some activities) and high (full integration of the target company) degree of 
integration. These studies also reveal ambiguous results. Taking further studies into consideration therefore does not lead to new insights.

The results for the second hypothesis, structural linking, remain unclear as well because, again, only few variables were tested. Statements made in the studies analysed about issues of structural integration are sometimes of a rather generic nature: Bamberger (1994) examines changes in the organisational structure, measured by the number or reorganisations since the acquisition. He shows that transactions with a maximum of one reorganisation are more successful than those with at least two reorganisations. Gerds (2000) analyses the constructs "linking of leadership structures" and "operational linking of business units" and reports that the latter construct has a positive influence on success. Thus the results regarding $H 2$ remain incomplete again.

Insights on $H 3$, which is concerned with the redesign of processes, were missing. The review of 19 additional studies also does not lead to new results here. It is therefore impossible to decide on this hypothesis. The following three hypotheses, which are concerned with harmonising systems, overcoming resistance and transferring knowledge, already received support. Considering the additional studies, there is an abundance of variables testing the dimension of systems and resources that support the previous results. For instance, Robbins and Stylianou (1999) report a significantly positive influence of an IS systems integration on success. With respect to the resources dimension, Schweiger and Denisi (1991) regard communication mainly as a means for reducing uncertainties. Gerpott (1993) lists eleven communication instruments that can be divided into formal and informal measures and that all, but for a few exceptions, positively influence success. The resource transfer between the acquiring and the acquired companies is addressed by Capron and Hulland (1999) and Meyer and Lieb-Dóczy (2003). Capron and Hulland observe a redeployment of resources (brands, sales forces and general marketing expertise) between companies. With respect to achievable synergy and success, they only find few significant connections. However, the transfer of general marketing expertise in both directions seems to have a positive effect on success. Meyer and Lieb-Dóczy (2003) show that a resource transfer from the acquiring to the acquired company also has a positive effect on success. Cannella and Hambrick (1993) investigate the influence of a loss of power and status within the organisation, motivating managers to drop out of the company. They find that the prevention of such a loss leads to a positive effect on success.

With respect to the context variables, there are a variety of further results. Cannella and Hambrick (1993) and Morosini, Shane and Singh (1998) refer exclusively to the product and market relatedness but cannot detect any effect of these variables. Therefore the result for $H 7$ does not change. The findings regarding relative size are mixed. 
Hunt (1990) and Morosini, Shane and Singh (1998) argue that acquisitions are particularly promising in cases where the acquirer is considerably larger than the target as the integration will be easier to handle. Others, however, report no or a non-significant effect. In contrast to that, Bamberger (1994) and Larsson and Finkelstein (1999) show that a small target will provide only a few starting points for realising value growth potentials. Thus the previously clear results for $H 8$ are qualified by these new findings. Finally, there was also an ambiguous result for $H 9$, which is concerned with cultural differences. On the one hand Bamberger (1994) and Weber (1996) report a negative influence of increasing cultural differences on success, while Morosini, Shane and Singh (1998) on the other hand found a positive effect of increasing cultural distance. Similarly, Larsson and Finkelstein (1999) show a positive effect of cross-border transactions on the realisation of value growth potentials. The findings for $H 9$ therefore remain unclear.

Finally, the use of success indicators in the 19 additional studies has been analysed. Above all, the omission of integration related success indicators was criticised. Fortunately, a review of the additional studies leads to a better result. Schweiger and Denisi (1991), for example, refer explicitly to aspects that are relevant for employees by using indicators such as perceived uncertainties, global stress, job satisfaction, or turnover, while Gerds applies factors like integration effectiveness and efficiency in order to estimate the quality of the integration process.

All in all, the integration of the 19 studies into the review that generally focus on post merger integration instruments has revealed only a few additional insights that are particularly relevant for $R \& D$. The following section will therefore outline the implications for future research based on the shortcomings outlined above.

\section{Implications for future research}

Instead of contributing to the clarification of the findings, integrating more studies has created even more confusion about variable relationships. In this way, the research field appears fragmented and incomplete - a situation that Cartwright and Cooper observed as early as 1990: "The research which exists has therefore no more than scratched the surface of the topic."

As a consequence, the question arises of how to design a study that is comprehensive in its content and sophisticated in its methodology. The desired study would comprise an integrated conceptual model that is tailored to the special requirements of R\&D units and that is made up of design, context and success variables and followed by an interindustry empirical analysis. With regard to content, other sources should be considered 
as studies up to now address the design variables only insufficiently in the structure and process dimensions. On the other hand, the system and resource dimensions have been adequately taken into consideration. In this respect, it is useful to include general findings of organization theory for each of the dimensions and thus to formulate a model that is based on theory. So far, none of the studies considered pursues this approach. For the deduction of the variables relevant to $R \& D$, special attention should be paid to the resource dimension. Moreover, the measurement of success should focus on R\&D and the employees of this division because they are responsible for the company's inventive performance. In other words, besides economic success indicators, technological and integration related success indicators should also be considered.

With respect to methodological concerns, further research should not focus on single cases but on an appropriately sized inter-industry sample to yield comprehensive results. The measurement of the integration success should focus on the post merger integration only and fade out other influences. In this context, Kirsch (1991) considers post merger integration to be an episode of reorganisation and integration in an ongoing process. Moreover, non-linear relationships between the variables should be accounted for - at least at the conceptual level - although the implementation would entail a significant statistical effort. The inclusion of multiple informants would be intricate as well even though the results would exhibit a higher validity. Nevertheless, the high relevance of the topic for securing competitiveness after an M\&A transaction would warrant the effort. 


\section{References}

Angwin, D. and Wensley, R. (1997). The acquisition challenge. Realising the potential of your purchase. Hot Topics, Warwick Business School, 1.

Bamberger, B. (1994). Der Erfolg von Unternehmensakquisitionen in Deutschland. Eine theoretische und empirische Untersuchung, Bergisch Gladbach.

Birkinshaw, J., Bresman, H. and Hakanson, L. (2000). Managing the post-acquisition integration process: How the human integration and task integration processes interact to foster value creation. Journal of Management Studies, 37, 395-425.

Brenner, M. S. (1990). R\&D cut before - not after - acquisition. Research Technology Management, 33, 15-18.

Brockhoff, K. (1989). Schnittstellen-Management. Abstimmungsprobleme zwischen Marketing und Forschung und Entwicklung, Stuttgart.

Bühner, R. (1990). Die Bedeutung von Unternehmenszusammenschlüssen im Rahmen einer technologieorientierten Unternehmensstrategie. ifo-Studien, 36, 17-40.

Burns, T. and Stalker, G. M. (2001). The management of innovation, Oxford.

Cannella, A. A. and Hambrick, D. C. (1993). Effects of executive departures on the performance of acquired firms. Strategic Management Journal, 14, 137-152.

Capron, L. and Hulland, J. (1999). Redeployment of brands, sales forces, and general marketing management expertise following horizontal acquisitions: a resource-based view. Journal of Marketing, 63, 41-54.

Cartwright, S. and Cooper, C. L. (1990). The impact of mergers and acquisitions on people at work: Existing research and issues. British Journal of Management, 1, 65-71.

Chakrabarti, A. K. (1990). Organizational factors in post-acquisition performance. IEEE Transactions on Engineering Management, 37, 259-268.

Chakrabarti, A. K. and Burton, J. (1983). Technological characteristics of mergers and acquisitions in the 1970s in manufacturing industries in the US. Quarterly Review of Economics and Business, 23, 81-90.

Chakrabarti, A. K., Hauschildt, J. and Süverkrüp, C. (1994). Does it pay to acquire technological firms? R\&D Management, 24, 47-56.

Chakrabarti, A. K. and Souder, W. C. (1987). Technology, innovation and performance in corporate mergers: A managerial evaluation. Technovation, 6, 103-114.

Datta, D. K. (1991). Organizational fit and acquisition performance: effects of post-acquisition integration. Strategic Management Journal, 12, 281-297.

Datta, D. K. and Grant, J. H. (1990). Relationships between type of acquisition, the autonomy given to the acquired firm, and acquisition success. An empirical analysis. Journal of Management, 16, 29-44.

Ernst, H. (2002). Ursachen eines Informant Bias und dessen Auswirkung auf die Validität empirischer betriebswirtschaftlicher Forschung. Zeitschrift für Betriebswirtschaft, 73, 1249-1275.

Gerds, J. (2000). Post Merger Integration. Eine empirische Untersuchung zum Integrationsmanagement, Wiesbaden. 
Gerpott, T. J. (1993). Integrationsgestaltung und Erfolg von Unternehmensakquisitionen, Stuttgart.

Gerpott, T. J. (1994). Abschied von der Spitze. Eine empirische Studie zur Höhe und zu Determinanten der Ausscheidensquote von Top Managern akquirierter deutscher Unternehmen. Zeitschrift für betriebswirtschaftliche Forschung, 46, 4-31.

Gerpott, T. J. (1995). Successful integration of R\&D functions after acquisitions: an exploratory study. R\&D Management, 25, 161-178.

Haag, T. (1995). Beteiligungsstrategien zur Erschließung von Innovationen, Wiesbaden.

Hagedoorn, J. and Duysters, G. (2002a). The effect of mergers and acquisitions on the technological performance of companies in a high-tech environment. Technology Analysis \& Strategic Management, 14, 67-85.

Hagedoorn, J. and Duysters, G. (2002b). External sources of innovative capabilities: the preference for strategic alliances or mergers and acquisitions. Journal of Management Studies, 39, 167-188.

Hall, B. H. (1987). The effect of takeover activity on corporate research and development. In Auerbach, A. J. (ed.), From corporate takeovers. Causes and consequences. Chicago et al., 69-100.

Hall, B. H. (1990). The impact of corporate restructuring on industrial research and development. Brookings Papers on Economic Activity, 1990, 85-124.

Haspeslagh, P. C. and Jemison, D. B. (1991). Managing acquisitions. Creating value through corporate renewal, New York.

Hauschildt, J. (1997). Innovationsmanagement, München.

Hitt, M. A., Hoskisson, R. E. and Ireland, R. D. (1990). Mergers and acquisitions and managerial commitment to innovation in m-form firms. Strategic Management Journal, 11, 29-47.

Hunt, J. W. (1990). Changing pattern of acquisition behaviour in takeovers and the consequences for acquisition processes. Strategic Management Journal, 11, 69-77.

Larsson, R. and Finkelstein, S. (1999). Integrating strategic, organizational, and human resource perspectives on mergers and acquisitions: a case survey of synergy realization. Organization Science, 10, 1-26.

Link, A. N. (1988). Acquisitions as sources of technological innovation. Mergers \& Acquisitions, 23, 36-39.

Meyer, K. E. and Lieb-Dóczy, E. (2003). Post-acquisition restructuring as evolutionary process. Journal of Management Studies, 40, 459-482.

Morosini, P., Shane, S. and Singh, H. (1998). National cultural distance and cross-border acquisition performance. Journal of International Business Studies, 29, 137-158.

Morosini, P. and Singh, H. (1994). Post-cross-border acquisitions. Implementing 'national culture-compatible' strategies to improve performance. European Management Journal, 12, 390-400.

Napier, N. K., Simmons, G. and Stratton, K. (1989). Communication during a merger. The experiment of two banks. Human Resource Planning, 12, 105-122.

Nicolai, A. and Kieser, A. (2002). Trotz eklatanter Erfolglosigkeit: Die Erfolgsfaktorenforschung weiter auf Erfolgskurs. Die Betriebswirtschaft, 62, 579-596. 
Pieper, U. (1998). Wirkungen von Unternehmensakquisitionen auf Forschung und Entwicklung. Eine empirische Untersuchung aus der Perspektive des erwerbenden Unternehmens, Wiesbaden.

Puranam, P., Singh, H. and Zollo, M. (2003). A bird in the hand or two in the bush? Integration trade-offs in technology-grafting acquisitions. European Management Journal, 21, 179-184.

Robbins, S. S. and Stylianou, A. C. (1999). Post-merger systems integration: The impact on IS capabilities. Information \& Management, 36, 205-212.

Rüdiger, M. and Vanini, S. (1998). Das Tacit knowledge-Phänomen und seine Implikationen für das Innovationsmanagement. Die Betriebswirtschaft, 58, 467-480.

Schweiger, D. M. and Denisi, A. S. (1991). Communication with employees following a merger. A longitudinal field experiment. Academy of Management Journal, 34, 110-135.

Singh, H. and Montgomery, C. A. (1987). Corporate acquisition strategies and economic performance. Strategic Management Journal, 8, 377-386.

Souder, W. C. and Chakrabarti, A. K. (1984). Acquisitions: Do they really work out? Interfaces, 14, 41-47.

Süverkrüp, C. (1992). Internationaler technologischer Wissenstransfer durch Unternehmenakquisitionen. Eine empirische Untersuchung am Beispiel deutsch-amerikanischer und amerikanisch-deutscher Akquisitionen, Frankfurt a.M. et al.

Thomson, N. and McNamara, P. (2001). Achieving post-acquisition success. The role of corporate entrepreneurship. Long Range Planning, 34, 669-697.

Tushman, M. L., Newman, W. H. and Romanelli, E. (1988). Convergence and upheaval. Managing the unsteady pace of organizational evolution. In Tushman, M. L. and Moore, W. L. (ed.), Readings in the management of innovation. Cambridge (MA), 705-717.

Weber, Y. (1996). Corporate cultural fit and performance in mergers and acquisitions. Human Relations, 49, 1181-1202. 